\title{
DARK SCREEN
}

\section{CLAUDIO PALAVECINO}

Profesor asistente adjunto, Escuela de Arquitectura de

la Universidad San Sebastián, Santiago, Chile

\section{Keywords}

$20 / 21$

Studio

Teaching

Adaptability

Essay
Confinement forced the usual

body-presence of academic learning to

migrate to the digital environment. The

speed we had to implement and adopt

those teaching systems did not give

us time to reflect on their implications.

This text starts that discussion, analyzing the architectures of virtual

architecture education.

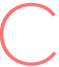
onfinement and social distancing. Not long ago, we would have still thought of these concepts as symptoms produced by some psychological disorder. Today, they regulate a cohabitation pact whose purpose is to take care of individual and collective health. The rapid expansion of COVID-19 forced governments, institutions, communities, and individuals to quickly redefine their routines and habits of sociability, work, or movement. The rise in the number of sick and deceased people turned the initial threat into a tragedy, making us - almost by force - aware that many of the activities we carried out daily were now a risk to our health or that of others.

Although the emergence of a pandemic was a scenario that the scientific community had anticipated for years, ${ }^{1}$ the option of instating measures in this regard involved questioning - and therefore modifying or replacing - the model that governs our relationship with the planet. As if the climate crisis was not sufficient evidence to stop the train of progress, the pandemic exposed our fragility as a species and that of an economic model projected to be permanent and unchangeable (Latour, 2020).

We did not question whether the inertia of this train of progress should be stopped; instead, we questioned how to adapt quickly and effectively to this new normality. In an accelerated fashion, to reproduce from their homes the productive scheme to which they were accustomed, an important part of the population adopted - or was forced to adopt - telework. ${ }^{2}$ So did the universities. Online teaching was the only option to stay active. This led to the implementation 

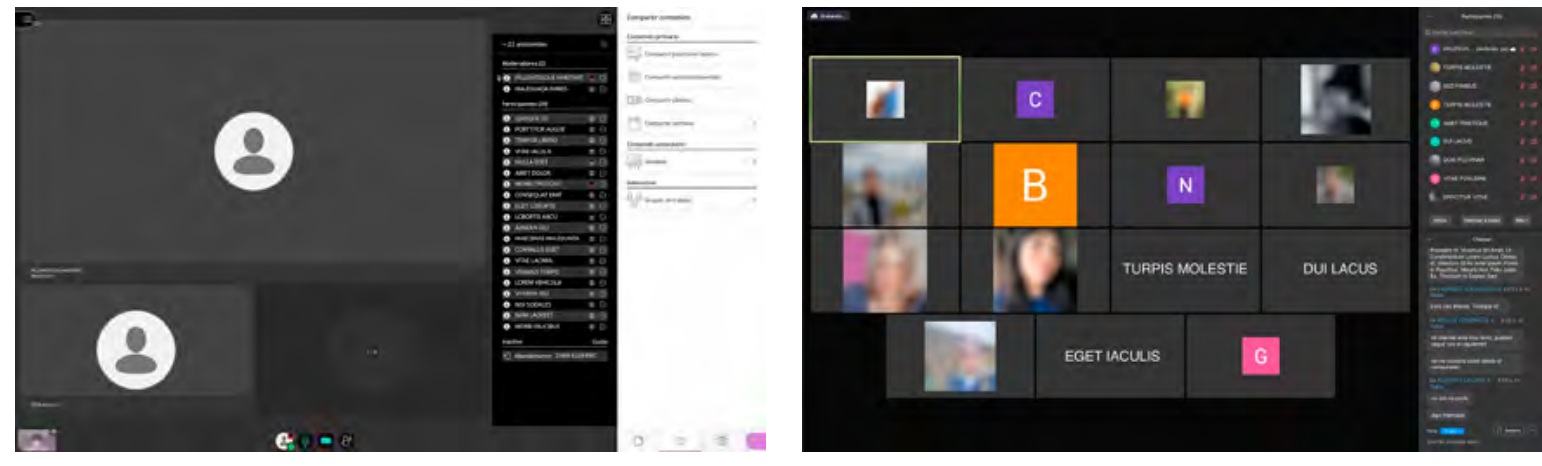

of protocols for teaching classes through video calls, digitize the literature in their libraries and hold numerous coordination meetings between their members. While online university teaching platforms such as OpenCourseWare, ${ }^{3}$ Coursera, ${ }^{4}$ or YouTube channels from different institutions allow them to stream content and study dynamics remotely, its function is oriented to autonomous and complementary learning of students, not to run the university as if it were an online service.

Given the urgency of maintaining the productive inertia of institutions operating under a late-capitalist scheme, we did not question the effects that moving the university to a completely digital space would have. Is it possible to convey the complexity and diversity of the academic environment through a screen? Are these institutions able to take on the scale of this problem or do they simply do their best within the constraints posed by this atypical health emergency scenario?

Faced with this situation, the communities of different schools of architecture in Chile showed a reasonable skepticism, if not an unspoken pessimism. It is not strange if we bear in mind that this adjustment implies reconstructing in a digital environment the interactions and work logics of the architecture studio, the irreducible matrix space of these institutions.

Within its multiple dimensions, the architecture studio acts as a social node that concentrates intellectual interests and practices around a field of malleable knowledge, continuously redrawing the discipline (for lack of a better term) through criticism and the cultivation of hypothetical thinking. An important part of this ecosystem is based on intense multimedia work, which makes freehand drawings, prints, or virtual models compatible, without prescriptions or limitations, assimilating their combinations within an exploratory process (Petit, 2018). If these practices, means, and interactions are enabled and conditioned by the space containing them, what happens when the studio takes place in an exclusively digital space? Can we recreate the processes, results, and findings of the studio - of the studio room, of the conventional physical places where architecture learning occurs - in an online stream?

The codes we have established to relate with each other in a studio room, auditorium, or university campus
FIG. 1 Captura de pantalla de la clase «Análisis de la arquitectura y la ciudad» a través de Blackboard Collaborate (Escuela de Arquitectura de la Universidad San Sebastián, noviembre de 2020). / Screenshot of the "Análisis de la arquitectura y la ciudad" class through Blackboard Collaborate (School of Architecture, Universidad San Sebastián, November, 2020). Elaboración propia / elaborated by the author.

FIG. 2 Captura de pantalla de la clase «Argumentos visuales y portafolio» a través de Zoom (Escuela de Arquitectura de la Universidad Diego Portales, octubre de 2020). / Screenshot of the "Argumentos visuales y portafolio" class through Zoom (School of Architecture, Universidad Diego Portales, October, 2020). Elaboración propia / elaborated by the author. 
FIG. 3 Captura

de pantalla de la

clase «Análisis de la

arquitectura y la ciudad»

a través de Blackboard

Collaborate (Escuela

de Arquitectura de

la Universidad San

Sebastián, noviembre de

2020). / Screenshot of the

"Análisis de la arquitectura

y la ciudad" class through

Blackboard Collaborate

(School of Architecture,

Universidad San Sebastián,

November, 2020).

Elaboración propia /

elaborated by the author.

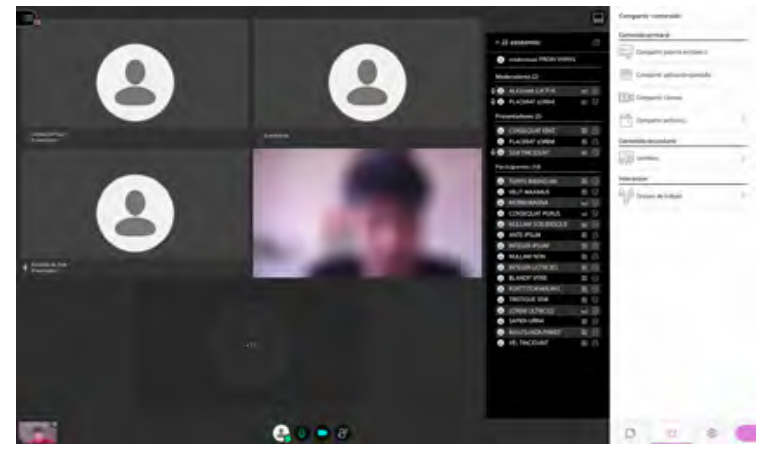

3

are conditioned by the physical constraints inherent to these places, the way these are designed and the bodily aspects of those who inhabit them. The sheets of paper pinned up to the interior wall of a room so an academic committee can see them; a slideshow projected onto a canvas while being presented by students; a round table in which allocutions and silences are agreed with simple glances and gestures; a chance encounter in a corridor; or even the prolonged applause of an audience after a lecture: they are all the product of bodily agreements and conditions of physical space. In the digital studio room, however, all those situations are subordinate to a screen.

\section{The Screen}

Decades ago, it was speculated that after the dissemination of global-scale communication networks, the advent of cities and architectures celebrating the fusion of digital and physical spaces would be inevitable (Mitchell, 2001). However, few imagined thousands of students and academics interacting through the screen of a computer, a tablet, or a smartphone on a regular and long-term basis. ${ }^{5}$ The screen - its interfaces, features, and technological limitations - not only alters how we learn and communicate architecture but also defines new conditions and powers typical of the digital studio.

These new attributions of the screen can be synthesized into three instances. First, the screen operates as a border. Situations occurring on either side are physically separated. Just like a glass partition, the screen separates the bodies, allowing them to be seen but isolating them in different rooms. A shared place of coexistence and complicity cannot be built and, in view of that, we agree that the transmission through the screen will simulate the interactions and codes of the usual architecture studio.

Secondly, the screen acts as a mediator, for only what is transmitted through it can be represented. The shared space between students and teachers is represented by a real-time video frame, similar to a television broadcast. In this scenario, the digital studio room must compete for the limited attention span that students can provide in comparison to other online stimuli (Goldhaber, 1997). In parallel to the class, google searches are made, messages are sent through WhatsApp, and photos are 

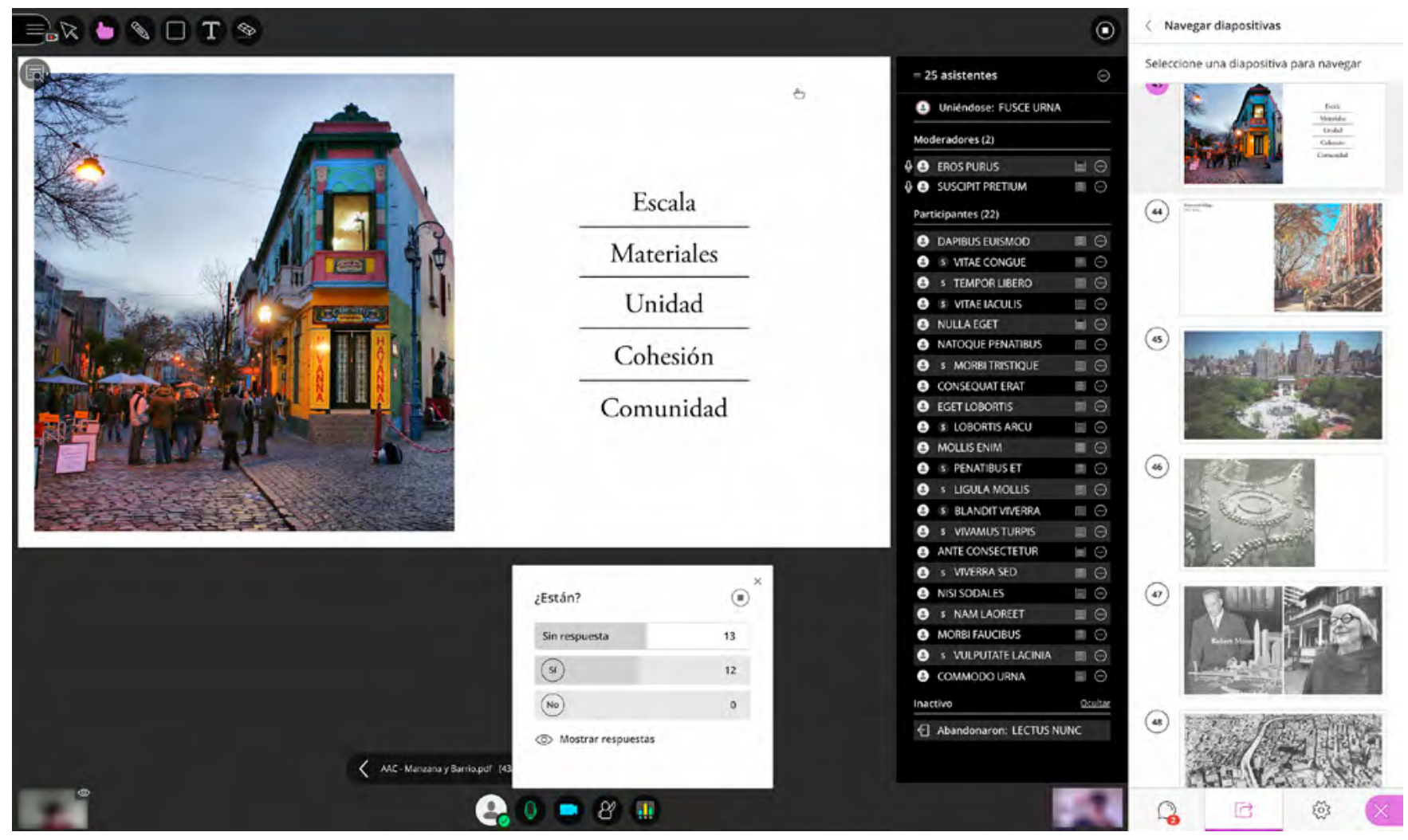

posted on Instagram. All of these activities are managed through visual interfaces, occupying and interrupting the surface of the screen. Thus, even if it operates as a mediator, its mediation does not mean a consensus on how the different members should instrumentalize this space. If the usual studio room can be understood as a place of consensus around shared activities, the screen is a disputed space in which the digital studio room is just one more agent looking for attention.

Finally, the screen employs a deforming force by subjecting all bodies and forms of expression to the limitations of a two-dimensional surface. The architecture we are communicating, learning, socializing, validating, and reproducing is born and dies on the flat surface of a screen. That is, it is a knowledge that exists in a quadrangular layer of pixels that are on and off following controlled instructions of hardware and software, inheriting - in every possible way - their forms. It is an architecture that, by force, does not take place in physical space, does not occur in the city, and does not house human bodies. These realities within the screen are intended to be recreated through drawings, photographs, or plans, but they remain just like the two-dimensional representation - via screen - of a previous representation, the one we knew when we were in a tangible room.

Under the screen's regime, we have tried to maintain a coexistence similar to the one we had before confinement, while also adopting a number of new habits. We do not interact directly with other people
FIG. 4 Captura de pantalla durante la presentación de contenidos de la clase «Análisis de la arquitectura y la ciudad» a través de Blackboard Collaborate (Escuela de Arquitectura de la Universidad San Sebastián, diciembre de 2020). / Screenshot during a lecture of the "Análisis de la arquitectura y la ciudad" class through Blackboard Collaborate (School of Architecture, Universidad San Sebastián, December, 2020). Elaboración propia / elaborated by the author. 
but with their representations: a face broadcasting, a digitized voice, an avatar, and a name (usually imported from a database). Something similar occurs regarding architecture, which is limited to images that transmit content with greater or lesser efficiency. If the digital studio room can establish itself as a recognizable and functional space to the requirements of universities and schools, it is because of the accepted (not necessarily consented) codes of interaction, work, and representation among its members. The dark screen, however, represents the rupture of those codes.

The Dark Screen

It might seem like a minor gesture, but the dark screen - one or more black frames that remain after turning off the camera during the transmission of an online meeting ${ }^{6}$ - is the visual trace of an absence: that of a student who was present in the digital studio room and who, presumably, is no longer present. Both in online architectural studios and classes of other university careers, we witness this abandonment in the form of numerous dark frames, black mosaics that completely occupy Zoom's interface. While there are no statistics on this yet, academics at different Chilean universities have expressed the frustration of teaching classes in which not only the faces of students are not visible or their voices not heard, but it is also unknown whether they are or not on the other side of the screen. ${ }^{7}$

This is partly due to how the codes and actions of the usual studio room have been translated into the interface and functions of video conferencing software. These tools are based on permanent communication, simulation of a face-to-face encounter, and sustained attention to a real-time transmission, demanding to be in front of a screen for a long period of time. This implementation differs from the studio's usual flexible interaction protocols, which support different focuses and activities within its physical space.

We also cannot dismiss the limitations on internet access in Chilean students' homes ${ }^{8}$ and the absence of adequate resources for online education - for example, having adequate computers and home spaces that facilitate attention to online classes. Clearly, the transfer of the studio room to a digital, operational, and medially different infrastructure imposes technological and spatial conditions that make meetings and communications difficult. When cameras are deliberately turned off, this becomes a conflict that transcends those limitations.

If, as stated above, the screen is a space seeking attention, the dark screen expresses the undesirable resolution of that conflict, dyeing with uncertainty the pact that would allow the operation of the digital studio room. In this space, being present. Here we witness the dissociation between representation and presence because who is present is not necessarily physically on the other side of the screen. We may not notice the interruption that happens when someone leaves the 


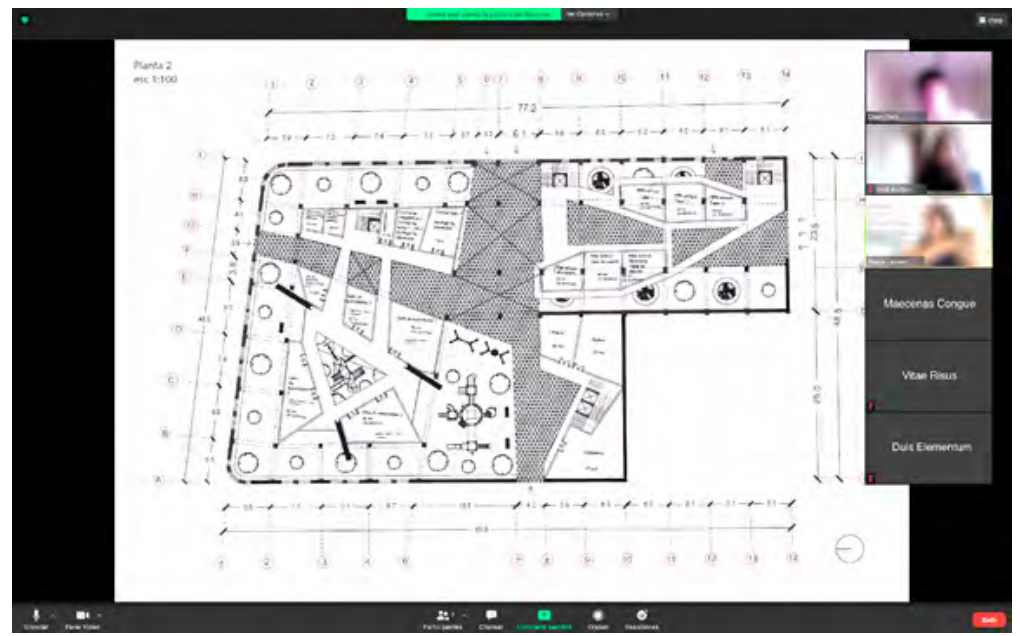

traditional room, but we do notice a disconnect when we do not know who is really with us in this digital space.

I assume, hypothetically, that the digital studio room can be understood as a place. Those who interact with other people through a software interface, trying to reproduce the activities they would develop in a physical place, can attribute properties of that place to a digital space, as if it were a provisional agreement. We could not conceive of the digital studio room on the same terms as we would of a tangible reality, yet we can notice that the experience with digital environments has a direct influence on how we perceive and act on our material reality. We could understand that physical presence runs smoothly between tangible environments and the information flows of the digital world, shaping our relationship with urban or domestic spaces (Picon, 2006). Thus, the bedroom, living room, or any other room from which we connect to online classes, partially blurs its programmatic standards and momentarily acquires the attributes of a studio room by containing and expanding what happens on the screen.

As these forms fade, people and projects become invisible, absent, the dark screen suspends the spatial agreement that was set to build this digital studio as a shared place. All events that it could potentially host are replaced by disconnected frames, without start or end, suppressing their architectural potential. Its destiny as a meeting place strays on an area that shows more honestly what is absent than what is truly happening. The paradoxical thing is that this loss does not contemplate arriving elsewhere, but witnessing an inconsistent architecture, erected at an indeterminate point between our homes and the incomplete and intermittent simulation of an architecture studio, which absorbs this conflict without a glimpse of a possible resolution.

If we can discuss the dark screen as an architectural expression, it is because it can be represented in a virtual space. The conflicts it contains - from the technical difficulties that reduce communication and contact
FIG. 5 Captura de pantalla durante la revisión de avance de proyectos en el «Taller integrado de titulación» a través de Blackboard Collaborate (Escuela de Arquitectura de la Universidad Mayor, noviembre de 2020). / Screenshot during revisions for developing projects of the "Taller integrado de titulación" through Blackboard Collaborate (School of Architecture, Universidad Mayor, November, 2020). Elaboración propia / elaborated by the author. 


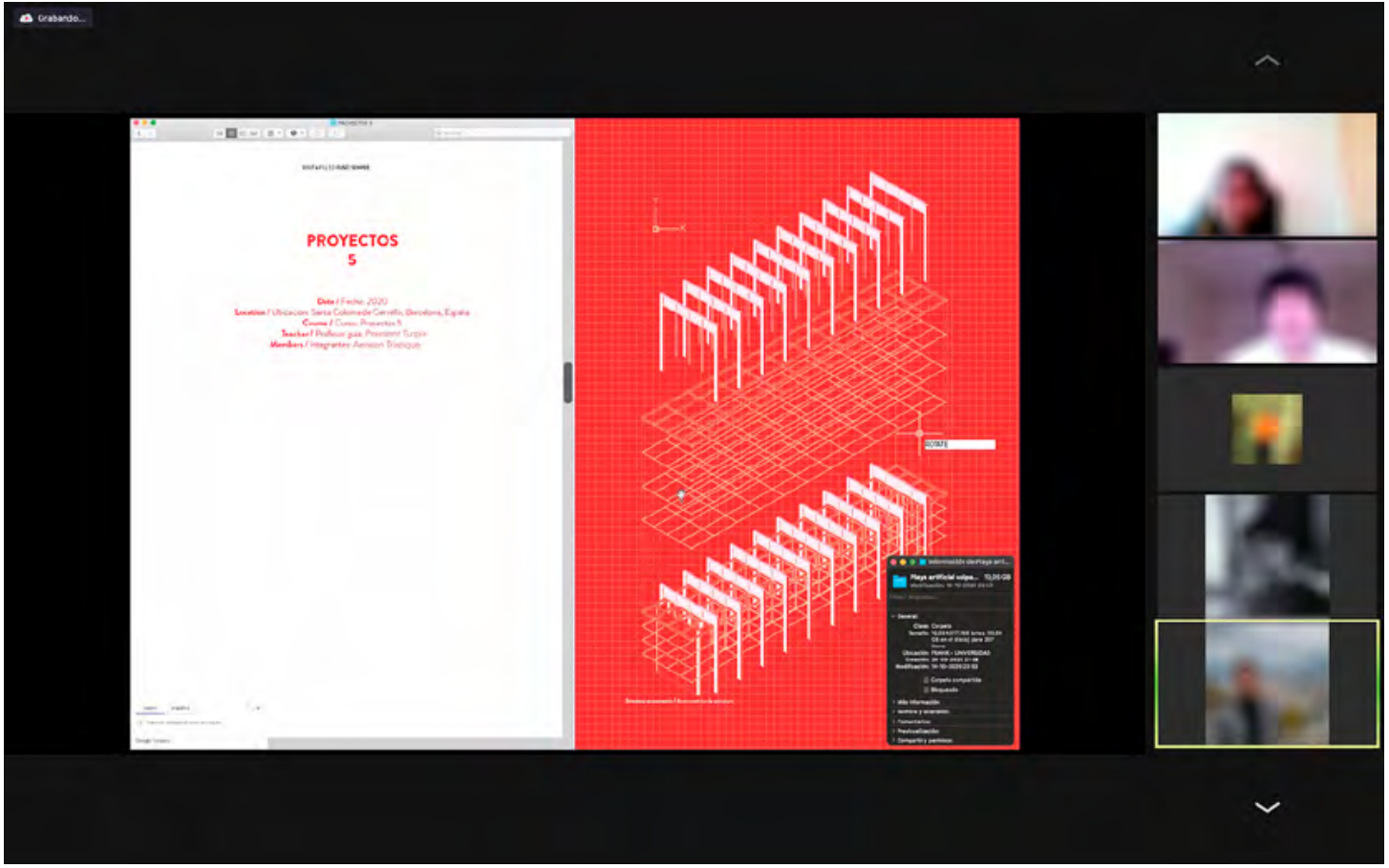

FIG. 6 Captura de pantalla durante la revisión de avance de proyectos en la clase de «Argumentos visuales y portafolio» a través de Zoom (Escuela de Arquitectura de la Universidad Diego Portales, noviembre de 2020). / Screenshot during revisions for developing projects of the "Argumentos visuales y portafolio" class through Zoom (School of Architecture, Universidad Diego Portales, November, 2020). Elaboración propia / elaborated by the author. to the refusal to be visible and present in the space it intends to recreate - are reflected in their incompatibility with the logics of architectural representation we know. This is not uncommon if we think that the supports and means we use to produce architecture are also vehicles to communicate it, to give it meaning when relating to others. As Bernard Tschumi (2002) pointed out regarding his Advertisements for Architecture, the architecture contained in the paper's space is unable to materialize the real architectural space, but its persistent reproduction through images seeks to trigger a desire for it. In the same way, but in the opposite direction, the dark screen - as a form of architectural production homologous to print - inhibits everything we want in architecture, triggering its rejection.

However, rather than representing a total affront to architecture, it is a rejection of its reproduction coming from the digital studio room or, more specifically, to the disciplinary construction of the architecture it emanates. The ideological ductility of architecture to build images at the service of any form of power implies that its mechanisms of representation inherit the values and crises of the institutions or structures that safeguard that power (Grau \& Goberna, 2014). Apparently motivated by the need to cling to previous representation paradigms and to powers and institutions that gave it stability, the dark screen captures the inability of architects to design a representation mechanism for those in front of the screen.

Having tried to decipher the dark screen from its condition of place and its representation, we get a dissociation between what we expect to happen there and the disarticulation of the attributes it possesses to meet those expectations. It does not 

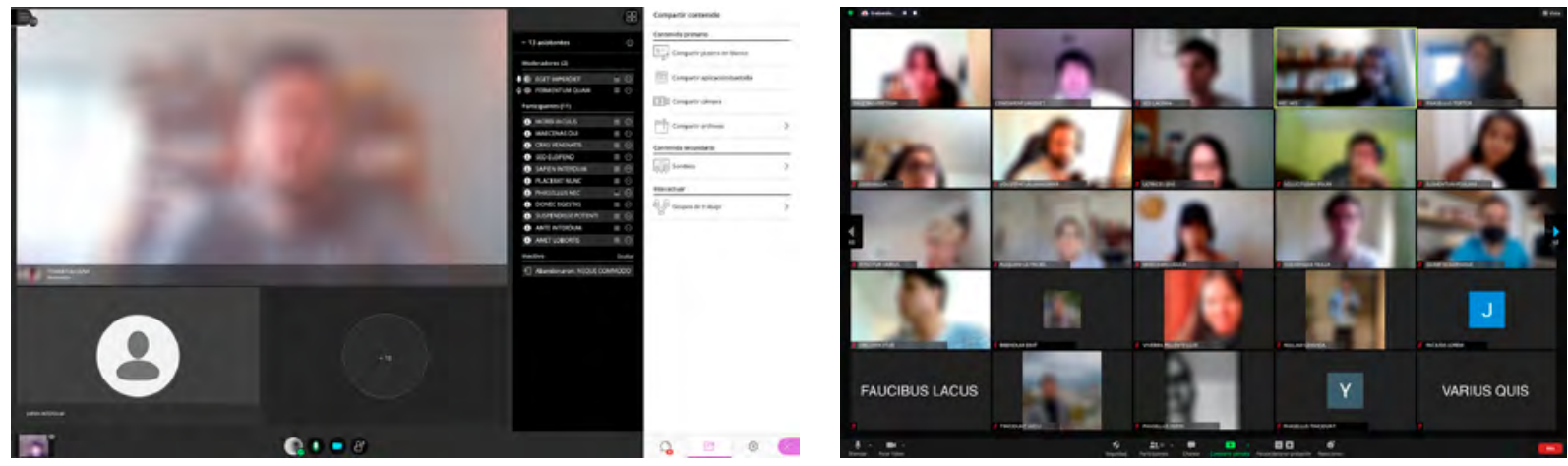

have a recognizable design, lacking form, depth, and matter. Still, we insistently try to fill it with content to maintain that what we see through this dark screen is conceptually a room, despite its persistent indifference (Tschumi,2005). Behind this uneasiness, the only obvious thing is an encounter with the darkness that the dark screen represents both literally and metaphorically.

Making a parallel to the concept of 'dark ecology' coined by Timothy Morton (2019), to delve into the darkness of a phenomenon implies an encounter with the mysterious and depressing but, in doing so, we trace a path of radical knowledge about it. As if it were the layers of chocolate, passing through the layers of this darkness involves savoring the bitter outer crust to reach the sweetness of its center. That 'sweet darkness' reveals this phenomenon as something strange, rare, but apprehensible, something impossible to do at the beginning. In this darkness, it is no longer possible to observe other entities or contexts, but only to observe oneself, just as it happens when looking at our face reflected on the off screen of a monitor or cell phone. Within the sweet darkness of the screen, we could finally observe the digital studio room as it is.

Is the dark screen the expression of the academy's failure to educate, communicate, and produce architecture at a time when tragedy and uncertainty overwhelm people's lives? Is this the expression of an architecture - its institutions, figures, values, and ideologies - that, faced with the inability to adapt to a changing society and culture, remains irrelevant, in darkness and silence? It is tempting to answer these questions. However, the purpose of formulating them is to illustrate the journey through this darkness and to position ourselves on a post-cryptic plane: What can we learn from the dark screen?

\section{The Other Side of the Dark Screen}

The fragility and darkness of the digital studio room allow, paradoxically, to render the personal dimension of that place visible. The studio - to generalize, all the spaces where we usually teach and learn architecture - seems to be sustained by a triad of carefully interconnected places, agents, and production (Palavecino, 2018). In the room, the place is inaccurate, or the production is reduced; but
FIG. 7 Captura de pantalla durante una sesión de conversación con estudiantes en la clase «Incertidumbres: el proyecto y la práctica de la arquitectura bajo cuestionamiento», a través de Blackboard Collaborate (Escuela de Arquitectura de la Universidad San Sebastián, julio de 2020). / Screenshot during a conversation session of the "Incertidumbres: el proyecto y la práctica de la arquitectura bajo cuestionamiento," class through Blackboard Collaborate (School of Architecture, Universidad San Sebastián, July, 2020). Elaboración propia / elaborated by the author.

FIG. 8 Captura de pantalla al término de la presentación de proyectos de fin de semestre en la clase «Argumentos visuales y portafolio» a través de Zoom (Escuela de Arquitectura de la Universidad Diego Portales, diciembre de 2020). / Screenshot of the final presentation of the projects developed for the "Argumentos visuales y portafolio," class thorugh Zoom (School of Architecture, Universidad Diego Portales, December, 2020). Elaboración propia / elaborated by the author. 
the individual and collective agencies of those who make it up not only support the studio's performance but also fill the aforementioned deficiencies. It does not fill the void of the room that we knew before the pandemic, but it does manage to guide the interactions that precede it, articulating a provisional architecture, supported by communication and power agreements between people or, to be more precise, through dialogue and horizontality.

The dialogue brings together all the components of the architecture studio. It is not strange to consider it a place of intense social interaction. This is stated by Juan Herreros (2017), who conceptualizes the studio as a project built on a sustained dialogue between professionals, clients, or students, without academic or work distinctions; a common ground where all the demands, questions, and constrictions of its work system are deployed. In the same line, Amale Andraos and Dan Wood (2018) understand that the work of their office, WORKac, and that of the academic studios they teach, are the product of a conversation between their members, providing ideas, solving dissent, and giving consistency to their interests over time.

These and other cases recognize a common condition: the work of architects and architecture students is collective. Regardless of it being more or less common, the dialogue is inescapable. This makes sense in a digital space where, in the absence of physical constrictions or of consistency in the production and reproduction of images, the only thing that allows setting the class in motion is the conversation between its members. This dialogue involves all people present, concentrating their attention and managing to mediate the realities in which they converge.

Horizontality is also a product of the limitations of this scenario. The digital studio dissolves the hierarchies induced by the architecture and roles of the usual studio. A frontal or leading sector is no longer distinguished for the scholar, nor is a subsequent or peripheral remnant for students; there are no privileged spaces or strata, there is no central place, no accesses. In the digital studio, they all occupy the same space in a grid or a members' list, and all have the same tools to intervene in the transmission's course. ${ }^{9}$ The limitations of a video-conferencing interface allow to match the powers, attributes, and representation of those present in this digital space, blurring authoritarian forms and practices, while giving the same dimensions to roles that were previously differentiated. Under this logic, shifts, orders, times, transfers, exchanges, and tasks are agreed upon by those who participate in the digital studio, in a similar way to what takes place at a round table or a citizen meeting.

Although distinguished here as isolated aspects, the dialogue and horizontality of the digital studio are dependent and simultaneous: the action of the former is only possible because of the manifest condition of the latter. This conjunction means that according to the representation and visibility codes of the room we can recognize those on the other side of the screen. 
Their presence is relevant, verifiable in this common or shared place. This experience reveals needs and also projects possibilities about the future of this space beyond the recreation of its known dynamics in an online transmission. The digital studio can be implemented as a social hub contained in virtual reality interfaces, as a hub of activities, communication, and forms of representation flexible to the different personal and domestic situations of its members, or even as another station within a set of physical and virtual places where the learning of architecture occurs (Rebek, 2020).

This context requires schools to be sensitive to the spatial and temporal transgressions people are experiencing (Mitchell, 2020). In the particular scale of the digital studio, this happens from the moment we want to know who is present. We care about how they are, how they are feeling, and how they are living through this long period of confinement.

While the digital studio triggers interests and actions that could be described as distracting or unproductive to the regular studio programming, in doing so it revalues and consolidates human ties that might never have been considered in the traditional studio experience. This new reality could make possible an architectural studio designed from the alterity, which manifests itself with hospitality as its founding matrix. This hospitality welcomes the other as a being worthy of love and protection, whose life we care about and that, by seeing them as a neighbor - outside the roles or hierarchies of the usual workshop room -, we can understand. Under this approach, to understand is to allow the possibility of the other, their ideas, virtues, and wills, to be deployed in their own spaces, transforming the system that receives them (Giannini, 1997).

If the digital studio - designed outside the disciplinary frameworks of architecture - can potentially hold a space of understanding and recognition of the other, we could ask why architects do not design spaces that intentionally give value to those dimensions; that is, that respond to the affections, emotions, and longings of the people these should protect. In this sense, we should wonder - as professionals, scholars, or students who operate in the architecture studio -, why do we conceptualize this space without understanding those who inhabit it?

Perhaps this is a good time to challenge what we understand by architecture studio, as a place, as an institution, as an architectural project, and as a community. But let us not rush into giving solutions. Before we design, we should look again at our object of study, the dark screen, as we can now visualize that someone is on the other side. ${ }^{10}$ ARQ 
1 Given the high probability of emerging animal-based influenza outbreaks with the potential to turn into pandemics, in 2011, the World Health Organization, in collaboration with a network of 150 specialized laboratories around the world, made public Pandemic Influenza Preparedness program. The goal of this plan is to prevent the transmission and transport of pathogens that could spread a disease of this nature and implement actions to prevent a global health disaster (Parkin, 2018).

2 In November 2020, an estimated $22 \%$ of those 'occupied,' according to Chile's labor participation rate, performed their activities under the remote working mode, equivalent to 1.62 million people (Bravo and Castillo, 2020).

3 OpenCourseWare is an initiative led by the Massachusetts Institute of Technology since 2001, which aims to provide free access to the contents of its courses through a web platform. It currently contains resources from more than 2,500 online courses through the license Creative Commons (MIT OpenCourseWare, 2020).

4 Coursera is an online platform for education resources founded in 2011, which collaborates with more than 200 universities and companies worldwide. It currently has 76 million enrollees who, through its courses and programs, can obtain academic and professional certification (Coursera, 2020).

5 Since a sanitary state of emergency was declared throughout Chile in March 2020, architecture schools decided to implement their online class programs with a time structure and load similar to the previous ones, extending them throughout the entire 2020 academic year. This considers maintaining class schedules, 6 -monthly calendars, and quantity of evaluations. In many cases, additional recess dates for academics and students were scheduled.

6 Online sessions are held through video-conferencing software such as Zoom, Microsoft Teams, Google Meet, or Blackboard Collaborate. In these, each participant must enable the microphone and camera from their respective computer to participate.

7 Experiences from students and academics during 2020 can attest that the vast majority of those who connect to online classes keep their cameras and microphones off during sessions, as has happened at Universidad de Chile (Orellana, 2020), Universidad Católica de Temuco (Cea, García, Turra, et al., 2020), Playa Ancha (UPLA, 2020), de Valparaíso (Zúñiga, 2020), Católica de Chile (Ávila, 2020), del Desarrollo and San Sebastián (Mendía \& Pérez, 2020).

8 While 9 out of 10 households in Chile have internet access, nearly half of these connections are mobile, with plans of limited access and capacity, mainly used for social media and entertainment. This type of access would prevent students from connecting to online classes on a level playing field, both in schools and universities (Correa, 2020).

9 In video-conferencing software, such as Zoom, Microsoft Teams, and Google Meet, all members of the digital room can be recognized in a side listing and/or on a visual grid that can range from $2 \times 2$ to $9 \times$ 9 video frames, depending on the number of people connected and the platform settings. In Blackboard Collaborate, the web interface allows access to all members through a list but only supports a maximum of 4 simultaneous video frames that alternate according to the class activity.

10 Disclaimer: All faces, names, or other forms of identification for students and academics recorded in the images selected for this article have been edited to protect their privacy. 
ANDRaos, Amale; wood, Dan; Palavecino, Claudio. «La conversación en el corazón del proceso de diseño». Materia Arquitectura I7 (2018): 6-23.

Ávıl a, Sebastián. «Clases online, desafíos y aprendizajes de la comunidad uc en medio de la pandemia». Vive la Uc, I4 de mayo, 2020. <https://vidauniversitaria.uc.cl/noticias/clasesonline-desafios-y-aprendizajes-de-la-comunidad-uc-en-mediode-la-pandemia>

B RAVo, David; CASTILlo, Ernesto. Estudio longitudinal empleo-covidig: Datos de empleo en tiempo real. Última modificación I7 de noviembre, 2020. <https://www.uc.cl/site/efs/ files/II854/presentacion-estudio-longitudinal-empleo-covidignoviembre2020.pdf>

CEA, Fredy; GARCí A, Ricardo; TuRRA, Héctor, et al. «Educación online de emergencia: Hablando a pantallas en negro». CIPER, 8 de junio, 2020. <https://www.ciperchile.cl/2020/o6/o8/educacion-online-deemergencia-hablando-a-pantallas-en-negro/>

CORREA, Teresa. «Desigualmente conectados». CIPER, 8 de abril, 2020. <https://www.ciperchile.cl/2020/04/o8/ desigualmente-conectados/>

cou r S E RA. Coursera Inc. Accedido el 6 de diciembre de 2020 / accessed on December 6, 2020. <https://about.coursera.org/>

GIANNIN I, Humberto. «Hospitalidad y tolerancia (o de la tolerancia)». Estudios Públicos 66 (1997): 335-343.

GOLDHABER, Michael. «The Attention Economy and the Net». First Monday vol. 2, no. 4 (I997)

GRAU, Urtzi; G OBERNA, Cristina. «No nos representan». Materia Arquitectura Io (2014): 56-63.

HER RER Os, Juan. «El proyecto de la práctica». En Workshop I: Juan Herreros, editado por Rayna Razmilic y Ernesto Silva, I2-38. Santiago de Chile: Ediciones Universidad San Sebastián, 2018.

LAT OU R, Bruno. «Imaginer les gestes-barrières contre le retour à la production d'avant-crise». Traducido al español por Jocelyn Leyva Santoyo (disponible en http://www.bruno-latour.fr/node/852.html). AOC, 30 de marzo, 2020, https://aoc.media/opinion/2020/03/29/ imaginer-les-gestes-barrieres-contre-le-retour-a-la-productiondavant-crise/.

MENDíA, Rosario; PÉrEZ, Carlos. «Mechones 2020: La generación accidentada». La Tercera, 26 de junio, 2020. <https://www.latercera. com/tendencias/noticia/mechones-2020-la-generacion-accidentada /6BJIZV7YG5 HOVB7 GLGHX7 $7 \mathrm{WY}_{7} \mathrm{PY} />$
MIT OPENCOURSEWARE. MIT Open Learning, accedido el 6 de diciembre de 2020 / accessed on December 6, 2020. <https:// openlearning.mit.edu/courses-programs/mit-opencourseware>

MITCHELL, Edward. «The pandemic can break architectural education out of the cloister for good». The Architect's Newspaper, I2 de agosto, 2020. <https://www.archpaper.com/2020/o8/post-pandemicpotentials-opportunity-for-architectural-education-to-break-out/> мiт CHeLl, William. E-topia. Vida urbana, Jim, pero no la que nosotros conocemos. Barcelona: Gustavo Gili, 200 .

MORTON, Timothy. Ecología oscura. Sobre la coexistencia futura. Barcelona: Paidós, 20I9.

Orellana, Antonia. «Los desafíos que impuso el Covid-I9 al modelo universitario». Palabra Pública, 23 de julio, 2020. $<$ https://palabrapublica.uchile.cl/2020/07/23/los-desafios-covidI9-modelo-universitario/>

PALAVECino, Claudio. «Taller / Oficina: lugar, agentes, producción». Materia Arquitectura I7 (2018): 35.

PAR KIN, Simon. «Así será nuestra próxima pandemia global». El País, 27 de noviembre, 20I8. <https://elpais.com/elpais/20I8/ıo/ıo/ ciencia/1539182476_373009.html.>

PETIT, Emmanuel. «Espacio de teoría: el taller de arquitectura». Materia Arquitectura I7 (2018): 36-43.

PICON, Antoine. «Arquitectura y virtualidad. Hacia una nueva condición material». $A R Q 63$ (2006): IO-I5.

REB K K, Bika. «How hybrid teaching could help reinvent architectural education». The Architect's Newspaper, I4 de septiembre, 2020, $<$ https://www.archpaper.com/2020/o9/post-pandemic-potentialshybrid-teaching-reinvent-architectural-education/>

т SCHum , Bernard. «The Pleasure of Architecture». En What is Architecture?, editado por Andrew Ballantyne, I73-I83. London: Routledge, 2002.

TSсним I, Bernard. «Concepto, contexto, contenido». Arquine 34 (2005): 78-89.

UPLA NOTICiAs. «Cámaras apagadas: La difícil tarea de potenciar la expresión corporal en el aula virtual». Universidad de Playa Ancha Noticias, 20 de agosto, 2020. <https://www.upla.cl/ noticias/2020/08/20/camaras-apagadas-la-dificil-tarea-depotenciar-la-expresion-corporal-en-el-aula-virtual/>

ZÚ Ñ IGA, Alejandra. «El nuevo mundo virtual de las facultades de Derecho». El Mercurio Legal 24 (2020): 42-45.

\section{Claudio Palavecino}

<cpalavecinol@docente.uss.cl> 